\title{
Notas sobre el Arte Popular del Perú en las Tradiciones de Ricardo Palma
}

Por César Coloma Porcari 
Presidente del Instituto Latinoamericano de Cultura y Desarrollo, Miembro de Número del Instituto Ricardo Palma y Miembro de Número del Centro de Estudios Histórico-Militares del Perú. 
Las Tradiciones de don Ricardo Palma ofrecen mucha información sobre los más diversos aspectos del pasado de nuestro país. En anteriores Encuentros Internacionales hemos presentado ponencias (todas publicadas en "Aula Palma", de 2007 a 2013), sobre la culinaria peruana en la obra palmista, así como lo referente a la música y danza y los instrumentos musicales del Perú, las antiguas calles de Lima, la Flora del Perú, Palma y los monumentos históricos, y la Medicina tradicional peruana en las Tradiciones de Palma.

En el presente trabajo ofrecemos la escasa pero valiosa información que nos brinda el genial tradicionista sobre el arte popular del Perú. Hemos ordenado la información alfabéticamente, con el fin de facilitar la consulta a los investigadores. Cabe destacar que nos estamos refiriendo únicamente a los trabajos que pueden considerarse como arte popular, por lo que excluimos, en este estudio, las referencias que hace Palma a las manualidades y a los utensilios de uso doméstico que carecen de valor artístico. La relación es la siguiente:

\section{Alhajas}

Don Ricardo Palma, nuestro gran tradicionista, en "Lucas el sacrílego", se refiere a un personaje, Lucas de Valladolid, que "era un mestizo, de la ciudad de Guamanga, que ejercía en Lima el oficio de platero. Obras de sus manos eran las mejores 
alhajas que a la sazón se fabricaban". Muy cercano a los frailes agustinos, un día robó la custodia de la iglesia. Entonces "fundió el oro y engarzó en anillos algunas piedras". Más tarde ofreció "en venta seis magníficos anillos" fabricados con el oro y piedras preciosas de la custodia robada. (Palma 1968: 563).

\section{Escapularios}

El tradicionista, en "La niña del antojo", se refiere a que en los monasterios de clausura, las monjas y donadas fabricaban escapularios (Palma 1968: 559). Además, en "Los endiablados", cuenta que un personaje acudió a la iglesia de San Francisco de Lima, en donde se hizo "aplicar recios cordonazos por los frailes, beber cántaros de agua bendita y cubrirse el cuerpo de cilicios y escapularios" (Palma 1968: 1074). Por último, en "iFíate en el Justo Juez y no corras!", de su "Refranero", recuerda a un famoso bandido que rezaba la oración del "Justo Juez" para librarse de la justicia y tenía un escapulario. Ese amuleto era "uno de esos escapularios que trabajan las monjas del Carmen" (Palma 1968: 1184).

\section{Imágenes de madera}

En "Dos cuentos populares" (Palma 1968: 910-911), recuerda que la polilla "no respeta ni el manto real ni las efigies de los santos", y que en el caso de las esculturas motivo de la tradición, "les comió las orejas y el cuerpo, de modo que las puso inservibles para el culto". Por ello, en ese pueblo, se reunieron los notables y decidieron contratar un escultor para que fabricara santos nuevos, en especial una Virgen. Conseguido su propósito, don Pascual, el escultor, llegó al pueblo e informó a todos que debía "escoger buenos troncos", y se puso a recorrer el lugar en busca de la madera apropiada. En 'El Romeral', frente a la choza 
de 'Ño Pachurro', don Pascual eligió el tronco que le servía a ese personaje "para amarrar su asno". 'Ño Pachurro' se opuso tenazmente a que le cortaran su tronco, pero las autoridades lograron convencerlo entregándole dinero y aguardiente; y así se rebanó el madero hasta la mitad, dejando la base para que el dueño siguiera amarrando a su burro. Pero el cura decidió que en lugar de labrar una Virgen en el tronco, se tallara un San Saturnino, patrón del pueblo. Y "El día de la fiesta y estreno de la imagen, le cantaron al Santo las siguientes coplas:

Glorioso San Saturnino, que nunca os olvidéis vos de que fuisteis escogido para ser madre de Dios.

Naciste en El Romeral, enfrente de 'Ño Pachurro', y el pesebre de un burro vuestro hermano natural.

De raíz de árbol nacido, sin pecado original, has tomado forma humana por obra de don Pascual.

Dios te libre de polilla, y a nosotros del afán de andar en busca de tronco que te venga tas con tas. [...]"

Asimismo, en "La trenza de sus cabellos" se refiere al más tarde famoso escultor Baltasar Gavilán, refugiado en el convento de San Francisco de Lima, quien "empezó por labrar un trozo de madera y hacer en él los bustos de la Virgen, el Niño Jesús, los tres Reyes Magos, y, en fin, todos los accesorios del misterio de 
Belén". Y "Aunque las figuras eran de pequeñas dimensiones, el conjunto quedó lucidísimo, y los visitantes del guardián propalaban que aquello era una maravilla artística". Por ello, "Alentado por los elogios, Gavilán se consagró a hacer imágenes de tamaño natural, no solo en madera, sino en piedra de Guamanga, algunas de las cuales existen en diversas iglesias de Lima" (Palma 1968: 554).

\section{Imágenes de maguey}

En el Virreinato se empleó el tronco de la inflorescencia del maguey (Agave americana L.) como sustituto de la madera, para la fabricación de esculturas de carácter religioso. Don Ricardo Palma se refiere a ese material tradicional con el que se elaboró una gran cantidad de imágenes religiosas de distinta calidad.

En la tradición "Ciento por uno", Palma se refiere a un aficionado a la escultura que "se propuso labrar la imagen de la patrona", es decir, de la Virgen de Copacabana. Pero "talló un busto que le salió tan deforme, que provocó la burla general”. Decidió entonces viajar a Potosí, e ingresar, como aprendiz, al taller de un escultor. Con el correr del tiempo, aprendió el oficio y pudo labrar la imagen. El tradicionista reproduce lo que registra un cronista sobre la famosa imagen de la Virgen de Copacabana (Lago Titicaca): "El busto es de maguey bien estucado, con pasta muy compacta que lo hace parecer de madera. Tiene cinco cuartas, y la belleza del rostro maravilla. Sin ser de vidrio sus ojos, son tan hermosos, que no se dejan mirar, y ellos parece que le miran a uno lo más secreto del corazón" (Palma 1968: 287).

\section{Imágenes de piedra de Guamanga}

En las inmediaciones de la ciudad de Guamanga se encuentra un tipo de alabastro que don Ricardo Palma llama formalmente 
"piedra de Guamanga", y que fue muy empleado para la elaboración de imágenes religiosas. En su tradición "Los amantes de la Real Orden", Palma socarronamente menciona los "San Antoñitos de piedra de Guamanga" que las beatas debían vestir, junto con imágenes sagradas de otros materiales (Palma 1968: 131).

Asimismo, en "La trenza de sus cabellos", se refiere a Baltasar Gavilán, refugiado en el convento de San Francisco de Lima, quien se dedicó a esculpir imágenes sagradas. Y "Alentado por los elogios, Gavilán se consagró a hacer imágenes de tamaño natural, no solo en madera, sino en piedra de Guamanga, algunas de las cuales existen en diversas iglesias de Lima" (Palma 1968: 554). Además, en "San Antonio del fondo" se refiere a un callejón limeño en donde existía un altarcillo en el cual se rendía culto a San Antonio; este contenía "la efigie del santo, finamente labrada en piedra de Guamanga” (Palma 1968: 1092).

En cuanto a la "piedra de Guamanga" misma, Juan de Arona afirma que "es una preciosa piedra o alabastro que se encuentra en varias partes del Perú, como Puno y Recuay (pueblo cercano a Huaraz), que poseen la de mejor calidad, que es un alabastro ágata. Pero la de Ayacucho o antiguo Guamanga, aunque inferior a las otras, es la que ha dado el nombre por ser ese el único punto donde los naturales se dignan explotarla empleándola en varias obritas de tan admirable escultura, que gozan de fama en Lima".

Agrega que "Generalmente se inspiran esos indígenas escultores en la Sagrada Escritura, única enciclopedia de nuestros pueblos del interior". Y "La escena del Calvario, la más dramática, es la que generalmente presta asunto a los rústicos cinceles guamanguinos. Otras veces es una mesa de tinteros con todas sus piezas, inclusive la campanilla, que no da sonido metálico por supuesto, y varias figuras alrededor, representando indios emplumados" (Arona 1882: 272-273). 


\section{Pintura mural popular}

En Lima y otras ciudades del Perú, se acostumbraba pintar decoraciones diversas en los muros de casas y templos. Existían algunas de gran calidad artística, pero otras, hechas por manos de aficionados, eran burdas y desproporcionadas. Muy poca de esta pintura mural ha sobrevivido el paso del tiempo y la que existe es hoy sumamente apreciada.

En su tradición "De esta capa nadie escapa", Palma afirma que "Hasta que dejamos de ser colonia española, no había en Lima casa en cuyo traspatio no se vieran pinturas de churrigueresco pincel. Por lo regular se copiaba un cuadro representando la prisión de Atahualpa, la revolución de Almagro el Mozo, una jarana en Amancaes, el auto de fe de madama Castro, el paseo de Alcaldes, la procesión de las quince andas o cualquier otra escena histórica o popular".

Agrega que "El artista (y perdón por el dictado), retrataba en esos frescos los tipos más ridículos y populares, y la fisonomía de individuos generalmente conocidos por tontos". Además, "En los paseos públicos, en las alamedas de Acho y del Callao, también veíanse idénticos cuadros. Así, en la primera existió, hasta 1830, uno representando 'el mundo al revés', cuadro que, francamente, no carecía de originalidad y gracia, según me han dicho los viejos. Aparecían en él escolares azotando al dómine; la res degollando al carnicero; el burro arreando al aguador; el reo ahorcando al juez; el escribano huyendo del gatuperio; el usurero haciendo obras de caridad; el moribundo bendiciendo al médico y la medicina", etc.

Además, "muchos pulperos hacían pintar, en sus esquinas, un dragón, una sirena, un cupido desvergonzado u otro personaje mitológico. Algunos, los menos, mandaban pintar un San Lorenzo sobre parrillas, un San Sebastián asaetado, un San 
Pedro crucificado boca abajo, un San Cristóbal con el Niño a cuestas o cualquier otro santo e su devoción. Así, varias calles quedaron bautizadas con el nombre del adefesio pintado". Y en el barrio de Abajo el Puente un pulpero había mandado pintar la figura de "un hombre en la actitud de embozarse la capa, la cual se componía de un almácigo de cuernos superpuestos. En el sombrero del mamarracho leíase esta inscripción: 'De esta capa nadie escapa'”. El virrey Abascal mandó borrar esa pintura mural (Palma 1968: 854-856).

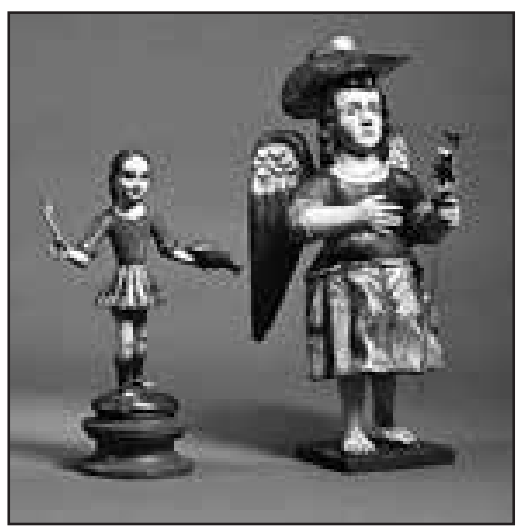

\section{Sombreros de Moyobamba}

En "Origen de una industria", Palma cuenta cómo en la ciudad de Santiago de Moyobamba se estableció la industria de sobreros de paja, gracias al interés de don Damián Nájar, gobernador de la provincia. Entonces "llegaron a Moyobamba tres guayaquileños, a los que su paisano Nájar acogió con benevolencia y comprometió para que se avecindasen en el lugar". Estos guayaquileños eran tejedores de sombreros y encontraron en los alrededores de Moyobamba "abundancia de la paja llamada "bombonaje" y "decidieron ocuparse en su antigua industria”. 
El gobernador Nájar "les pidió que enseñasen a los muchachos del pueblo, y siendo fácil y entretenido el aprendizaje, antes de un año hasta las mujeres eran diestras tejedoras de sombreros". Esta industria se desarrolló de tal manera en Moyobamba que los sombreros se comercializaban en todo el Perú y aún se exportaban al extranjero (Palma 1968: 1005).

El material empleado, la palma "bombonaje" (Carludovicapalmata Ruiz et Pavón), es descrito por don Ricardo Palma de esta manera: "Bombonaje - La paja especial que se encuentra en muchos afluentes del Amazonas, y que sirve para la fabricación de los sombreros llamados de 'jipijapa', sombreros, hasta hace poco, muy estimados y valiosos” (Palma 1896: 21). Y además, define "Jipijapa - Esta voz viene de la lengua 'yunga', y significa sombrero fabricado con la paja conocida por "bombonaje" (Palma 1896: 36; 1903: 165).

\section{Topo}

El "topo" es un prendedor fabricado en metal, generalmente en plata, con el cual se sujeta la manta que cubría a las mujeres indígenas. El tradicionista, al referirse a la "lliclla", afirma que es una "Especie de mantilla de bayeta que las indias se ponen cruzándola sobre el pecho, y prendiéndola debajo de la barba con una aguja grande, de oro o plata, a la que dan el nombre de "topo" (Palma 1903: 313).

Juan de Arona describe el "topo" como "alfiler, con que desde el tiempo de los incas se prendían la manta las peruanas" (Arona 1882: 482). Y la Real Academia Española define al "topo" como "alfiler grande con que las indias se prenden el mantón", agregando que proviene del quechua y que su uso se extiende a la Argentina, Chile y el Perú (DRAE 1939: 1230). 


\section{Bibliografía}

ARONA, Juan de: "Diccionario de peruanismos", Lima, Librería Francesa Científica J. Galland, 1882.

COLOMA PORCARI, César: "La culinaria peruana en las Tradiciones de Ricardo Palma", en "Aula Palma", vol. VI, Lima, Instituto Ricardo Palma, Universidad Ricardo Palma, 2007, pp. 169-2 14.

"La música y danza en las Tradiciones de Ricardo Palma", en "Aula Palma", vol. VII, Lima, Instituto Ricardo Palma, Universidad Ricardo Palma, noviembre 2008, pp. 41-69.

"Los instrumentos musicales del Perú en las Tradiciones de Ricardo Palma", en "Aula Palma", vol. VIII, Lima, Instituto Ricardo Palma, Universidad Ricardo Palma, diciembre 2009, pp. 55-74.

"Las antiguas calles de Lima en las Tradiciones de Ricardo Palma", en "Aula Palma" vol. IX, Lima, Instituto Ricardo Palma, Universidad Ricardo Palma, 2010, pp. 71-106.

"La flora del Perú en las Tradiciones de Ricardo Palma", en "Aula Palma" vol. X, Lima, Universidad Ricardo Palma, Instituto Ricardo Palma, diciembre 2011, pp. 59-90.

"Ricardo Palma y los monumentos históricos del Perú", en "Aula Palma", vol. XI, Lima, diciembre, 2012, pp. 71-93.

"La Medicina tradicional peruana en la obra de Ricardo Palma", en "Aula Palma" vol. XII, Lima, Instituto Ricardo Palma, Universidad Ricardo Palma, 2013, pp. 47-64.

PALMA, Ricardo: "Neologismos y americanismos", Lima, Imprenta y Librería de Carlos Prince, 1896.

“Papeletas lexicográficas”, Lima, Imprenta La Industria, 1903.

"Tradiciones peruanas completas", Madrid, Aguilar S. A. de Ediciones, Selecciones Gráficas, 1968.

REAL ACADEMIA ESPAÑOLA: "Diccionario de la lengua española", Madrid, Talleres Espasa-Calpe S. A., "Año de la Victoria” (1939). 